\title{
The versatile rhomboid (Limberg) flap
}

\author{
Leslie R Chasmar MD FRCSC
}

\begin{abstract}
LR Chasmar. The versatile rhomboid (Limberg) flap. Can J Plast Surg 2007;15(2):67-71.

The rhomboid (Limberg) flap can be used to close defects almost anywhere on the body. It is versatile in that a random pattern flap can be raised from any one or all corners of the rhomboid. The defect is filled with tissue of the same thickness and colour, and with good vascularity. The present paper demonstrates the versatility of the rhomboid flap.
\end{abstract}

\section{Le lambeau du rhomboïde (de Limberg) polyvalent}

Le lambeau du rhomboïde (de Limberg) permet de fermer des anomalies presque partout sur le corps. Il est polyvalent parce qu'il est possible de prélever un lambeau de la forme voulue sur l'un ou plusieurs des quatre coins du rhomboïde. L'imperfection est remplie de tissus de la même épaisseur, de la même couleur et d'une bonne vascularité. Le présent article démontre la polyvalence du lambeau du rhomboïde.

Key Words: Limberg flap; Rhomboid flap

$\mathrm{T}$ he purpose of the present paper is to demonstrate that a single flap can be used to close defects almost anywhere on the body. It is versatile in that a random pattern flap can be raised from any one or all corners of the rhomboid. The defect is filled with tissue of the same thickness and colour, and with good vascularity.

Professor AA Limberg of Leningrad devoted his entire career to flap design, publishing first on the subject in 1928. His first treatise in English was a chapter in Modern Trends in Plastic Surgery, edited by Thomas Gibson of Glasgow University (Glasgow, Scotland) in 1963 (1). In that chapter, he outlined his rhomboid flap. It is basically a parallelogram with two angles of $120^{\circ}$ and two of $60^{\circ}$ (Figure 1). These angles, of course, can be modified depending on the shape of the lesion or defect. All sides of the rhomboid and all sides of the flap are equal. As many as four flaps can be raised from one rhomboid, if required. Often, a myriad of flaps are outlined, but the student or resident is not given an opinion as to which one might be useful in the majority (Figure 2 ). The proper technique for raising these flaps is described. A literature search turned up 54 articles on the use of the rhomboid (Limberg) flap in all areas of the body and by several surgical specialties.

There are nine articles on its use for pilonidal sinus and three for hand surgery, as well as several examples of its use in ophthalmology and otolaryngology. This flap is obviously an attractive choice in many body areas.

The technique of its elevation is simple. The elevated flap requires sufficient subcutaneous fat, and dissection must be carried past its base to prevent an elevated bump when it is transposed.

Examples of its application in skin cancer, lupus, cystic acne, spina bifida, etc, are shown (Figures 3 to 15). It has special application for eyelid, floor of nose, alar rim and chin defects. It is proposed that the rhomboid (Limberg) flap, single

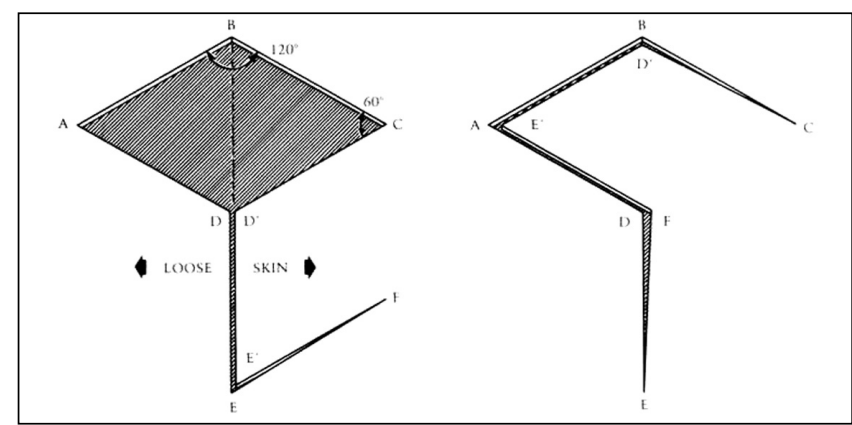

Figure 1) The rhomboid (Limberg) flap. The flap design places the longitudinal axis of the rhomboid excision parallel to the line of minimal skin tension

or multiple, can be applied widely with extreme safety and good cosmetic results.

The rhomboid (Limberg) flap is a transposition flap that, like the bilobed flap and the Z-plasty, depends on the pliability of the adjacent skin, which can be determined by pinching various areas between the thumb and forefinger (2).

In conclusion, I would propose that the rhomboid (Limberg) flap, single or multiple, can be applied with extreme safety and should be your first choice for many full thickness defects.

Presented at the 60th Annual Meeting of The Canadian Society of Plastic Surgeons, Quebec, June 14 to 17, 2006.

\section{REFERENCES}

1. Gibson T, ed. Modern Trends in Plastic Surgery. London: Butterworths, 1964.

2. Smith JW, Aston SJ. Grabb and Smith's Plastic Surgery. Boston: Little Brown and Company, 1991.

University of Saskatchewan, Saskatoon, Saskatchewan

Correspondence and reprints: Dr Leslie R Chasmar, University of Saskatchewan, Medical Arts Building, Suite \#441-750 Spadina Crescent East,

Saskatoon, Saskatchewan S7K 3H3. Telephone 306-652-9180, fax 306-652-2499, e-mail chasmar@sasktel.net 


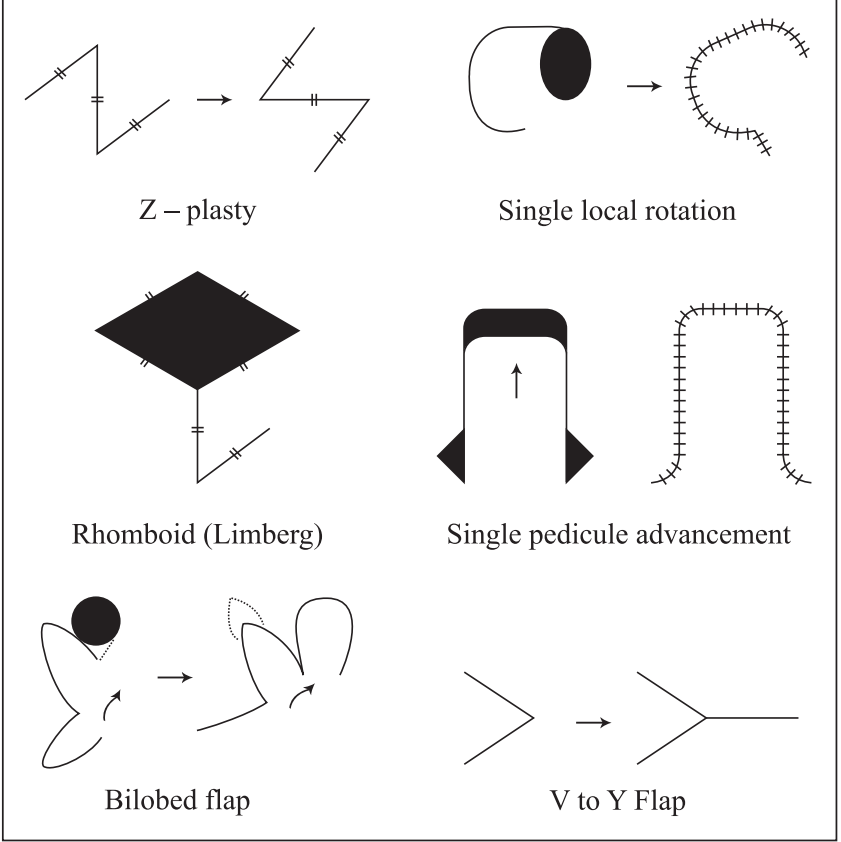

Figure 2) Multiple flap choices
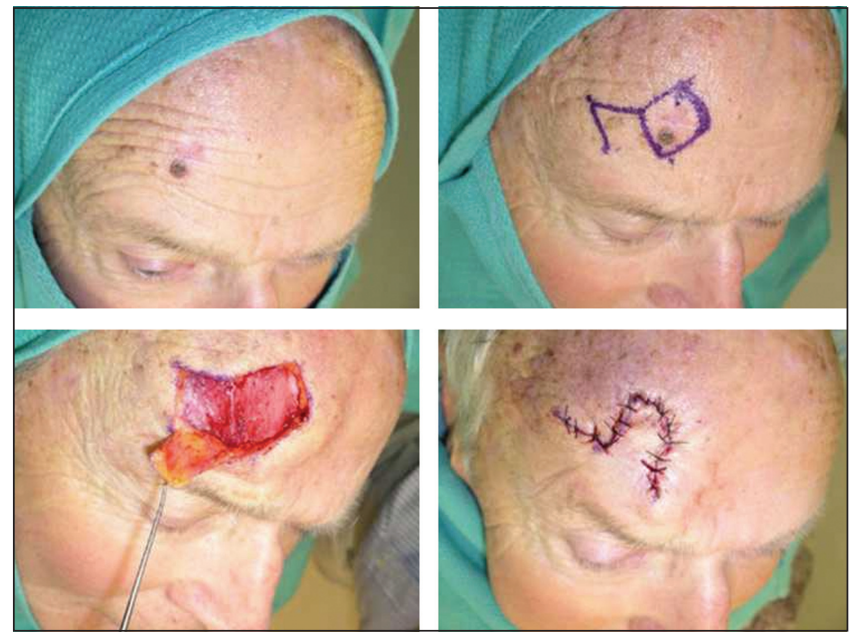

Figure 3) Basal cell carcinoma of the forehead

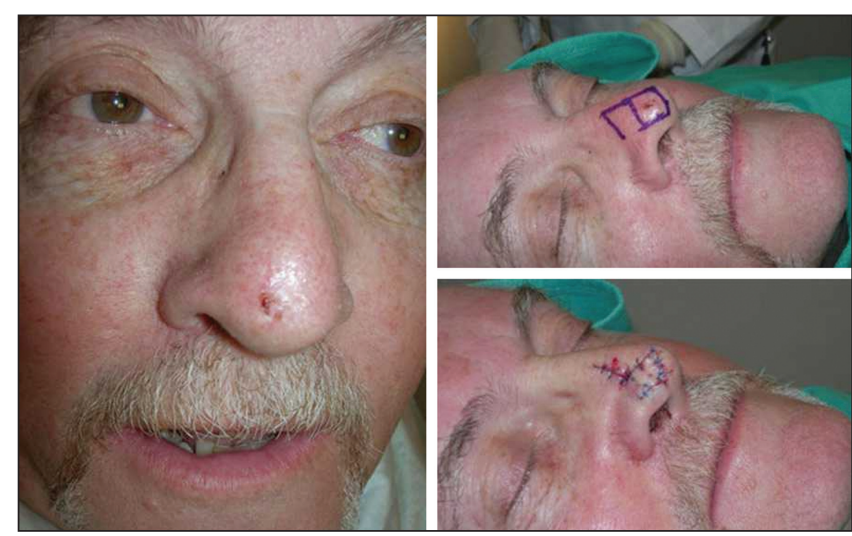

Figure 4) Basal cell carcinoma of the nose
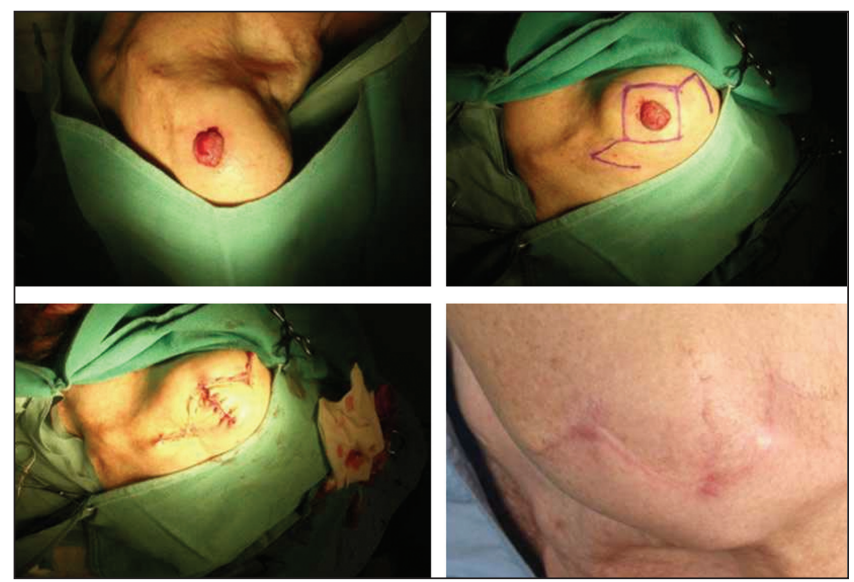

Figure 5) Basal cell carcinoma of the shoulder - double Limberg flap
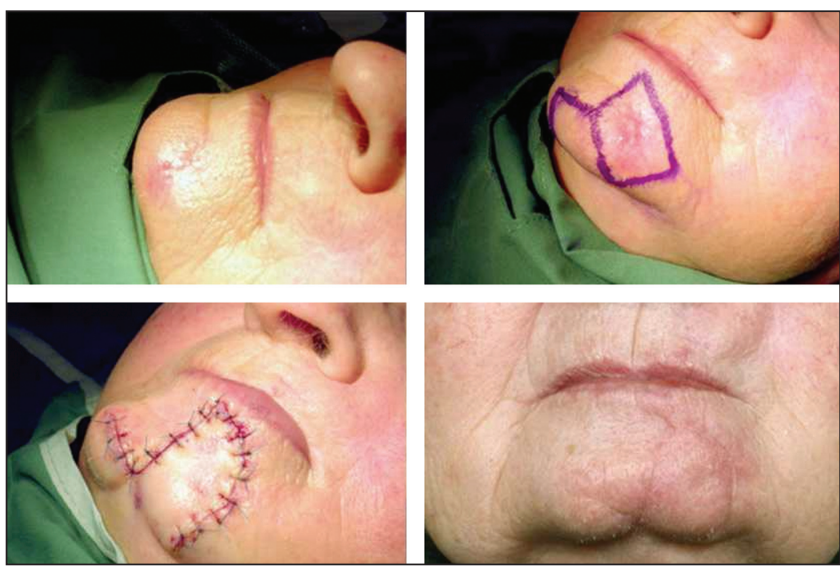

Figure 6) Residual basal cell carcinoma of the chin incompletely excised $\times 2$ 

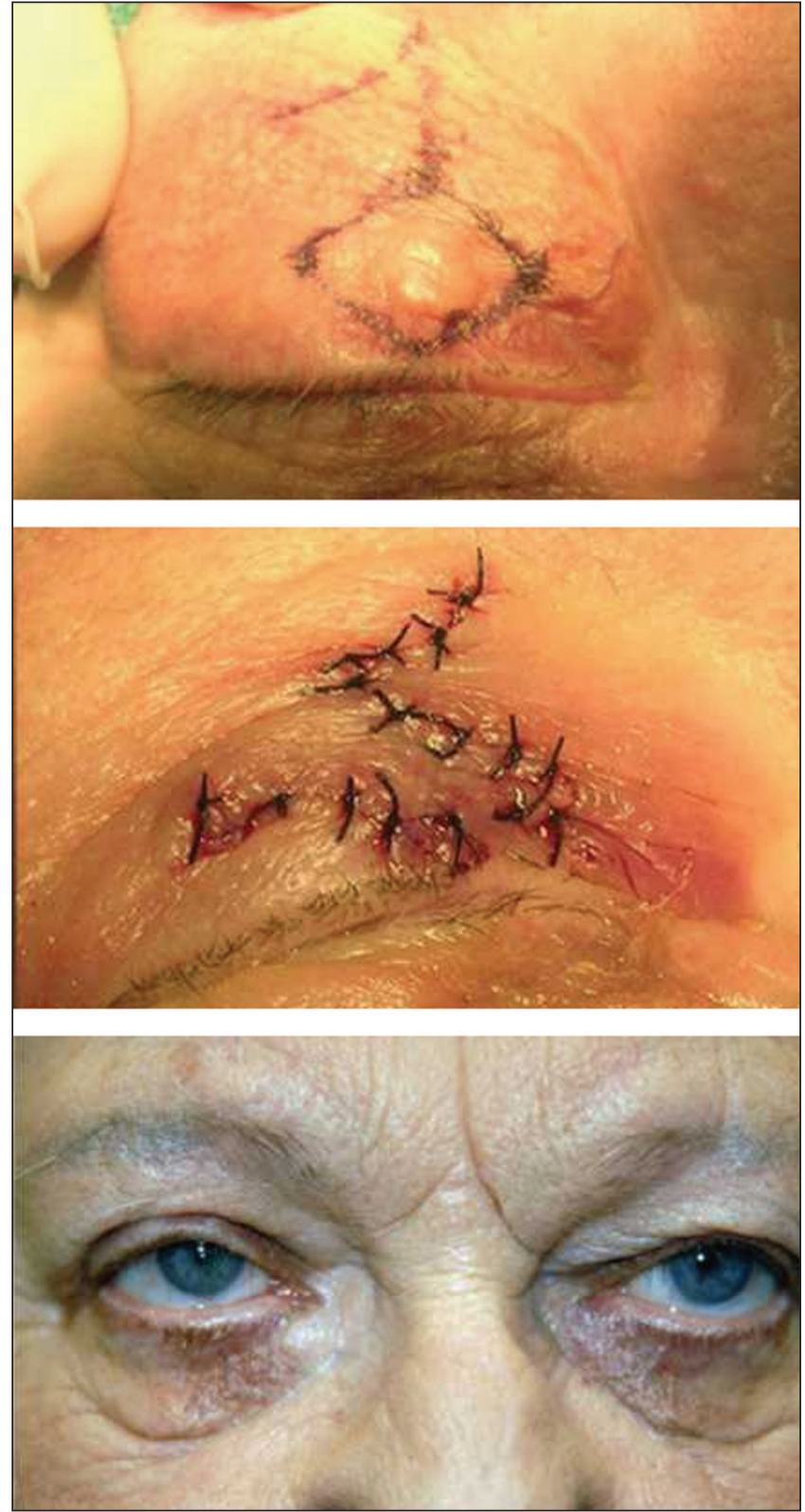

Figure 7) Basal cell carcinoma of the upper lid

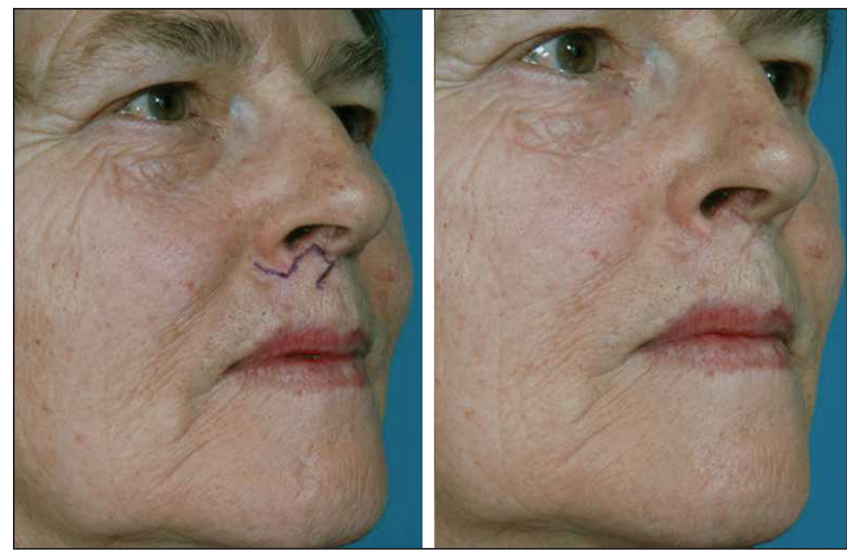

Figure 8) Limberg flap - floor of nose
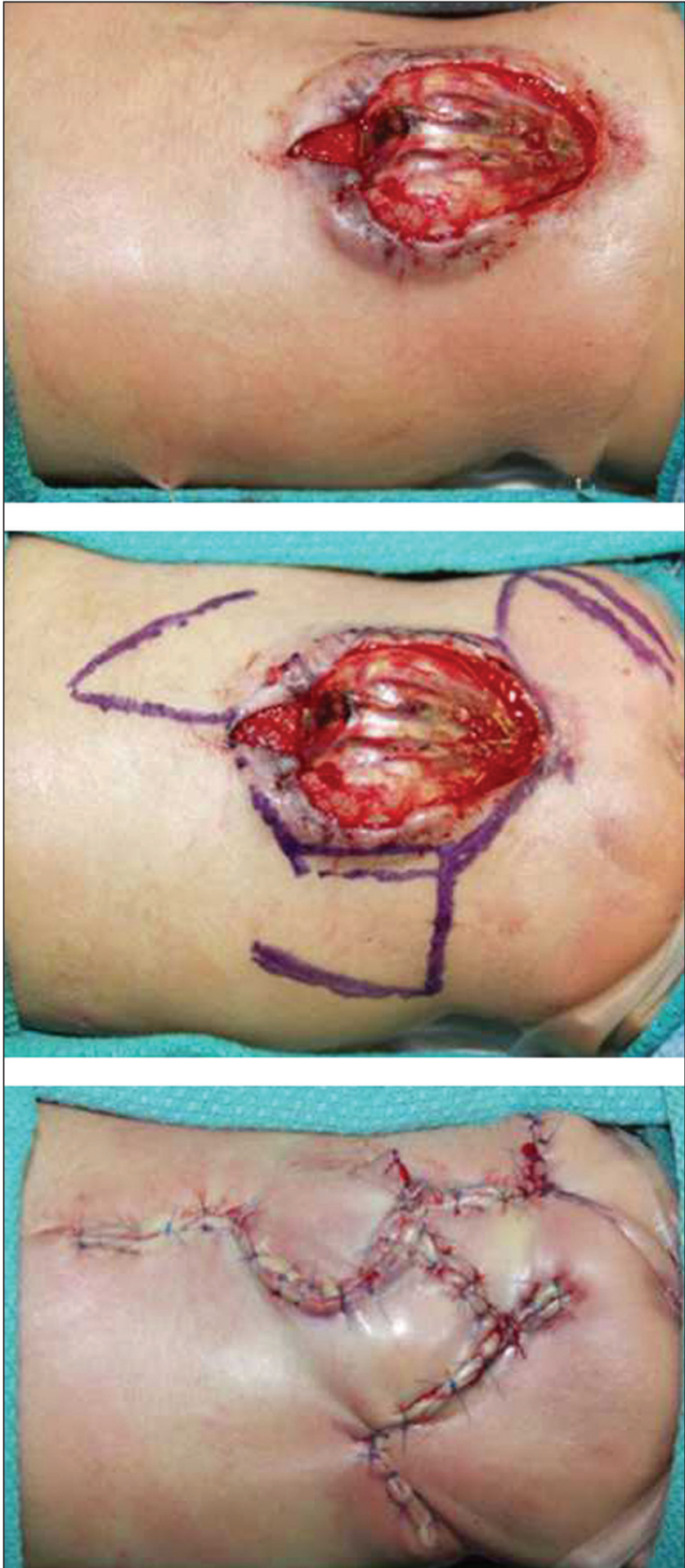

Figure 9) Triple Limberg flap - spina bifida (courtesy Dr Dale Classen) 


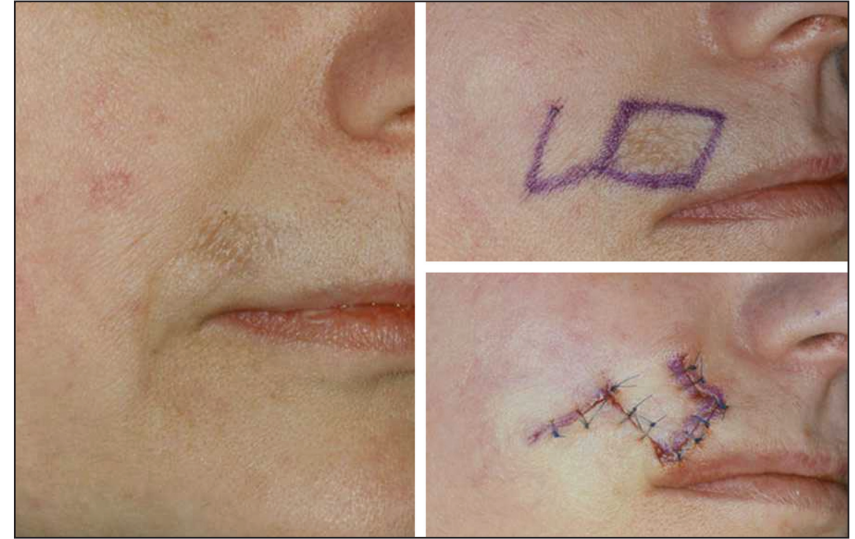

Figure 10) Lupus - right upper lip

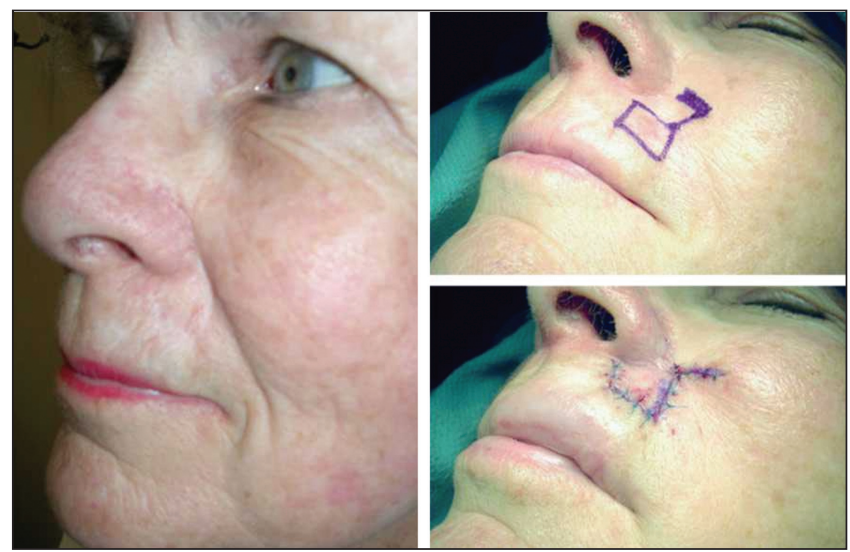

Figure 11) Basal cell carcinoma of the left cheek
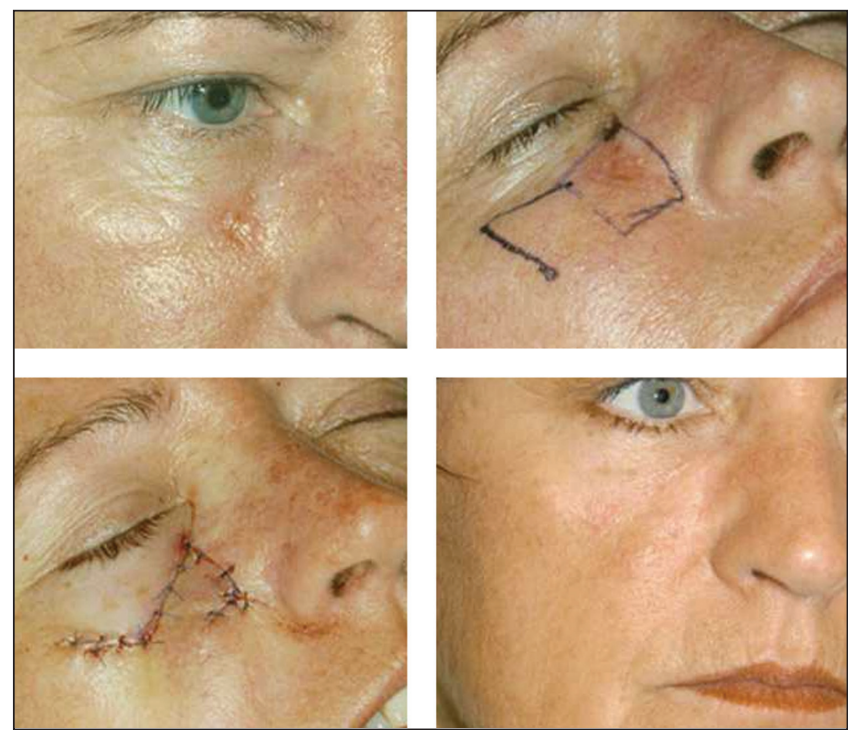

Figure 12) Basal cell carcinoma of the right nasolabial area
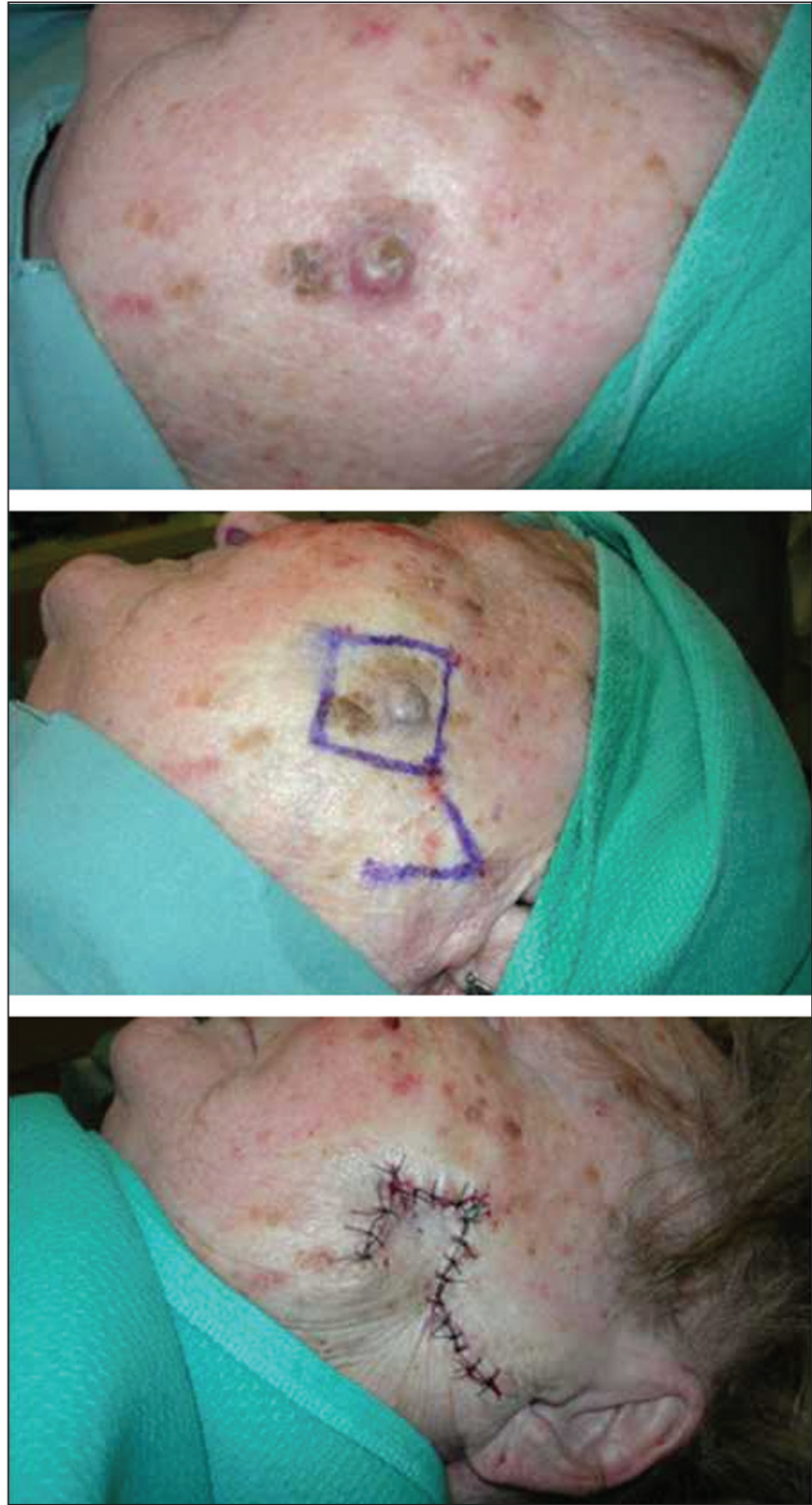

Figure 13) Keratoacanthoma and focal seborrheic keratosis 


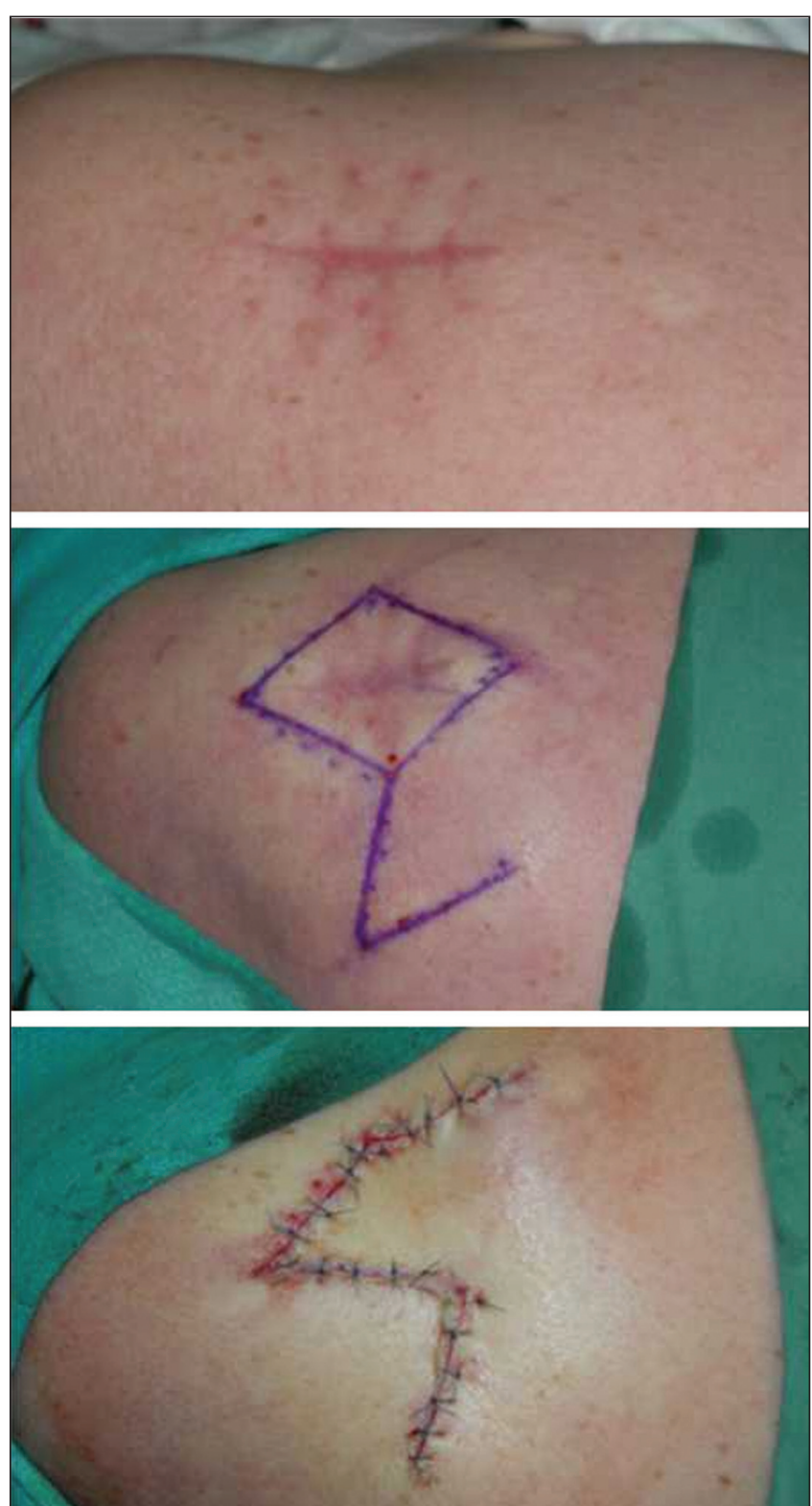

Figure 14) Basal cell carcinoma of the shoulder incompletely excised $\times 2$
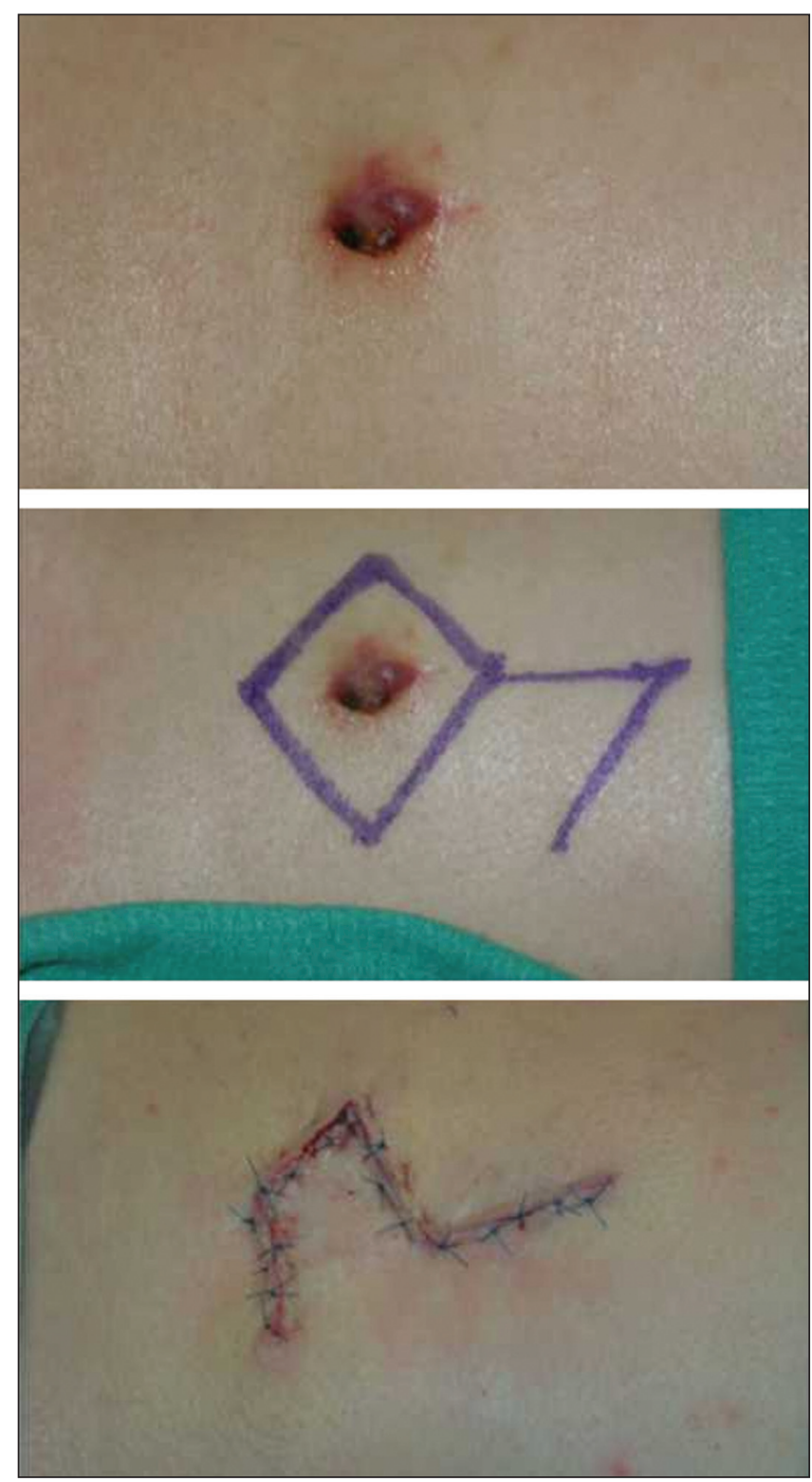

Figure 15) High-grade, undifferentiated, small round cell neoplasm incompletely excised $\times 1$ 